\title{
REUSING TILING WASTE IN THE CONSTRUCTION OF PAVEMENTS
}

\author{
Loubna Belakhdar, Mouloud Belachia, Houria Hebhoub* \\ University of Skikda, Algeria
}

The factories of tiles manufacturing, ceramics, marble, tile and brick generate an important quantity of waste, their recovery meets economic and environmental objectives. The objective of our research is to study the possibility of the reuse of tile manufacturing waste as aggregates in the construction of pavements. To carry out this experimental study we have made characterization tests on all the materials used. The study investigates the influence of substitution of recycled tarred waste aggregates in mixtures of bituminous gravels with rates of 10, 20 and $30 \%$ on mechanical performance (Duriez stability) and compared the results obtained with composite control samples ordinary aggregates (0\%). The results obtained show that the introduction of tiling waste into the formulation of a severe bituminous material has a positive influence on the mechanical performance.

Key word: valorization, tiling, duriez, body of roadway, waste

\section{INTRODUCTION}

The recovery and reuse of industrial waste in the field of civil engineering is a topical issue where researchers are trying to find other sources of supply of construction materials using this waste, and this reduces its volume, protect the environment and reduce the consummation of energy.

The Road's works are an interesting area for the recovery of waste (mines and quarries, industrial, metallurgical, demolition materials). These are recycled into pavements under five main types which are deep recovery, hot and cold recycling in place, cold planning and hot recycling (Cabrera et al, 2017) [4]. It is in this area that this study is part of which aims at reusing the waste of manufacture of tiling as aggregates in the realization of the base layers of the pavements for the valorization. Several researchers have focused on the recovery of industrial waste in the road sector.

Morsli et al, 2013 [12] investigated the possibility of incorporating asphalt aggregates from milling a surface layer with $10,20,30,40$ and $50 \%$ levels into a semi-grained bituminous mix, with the results obtained show that the addition of asphalt aggregates significantly improved the performance of the recycled mix, only the compactness and creep were problems at $50 \%$ addition.

Bendimerad and Zadjaoui, 2015 [3] have worked on the use of a recycled product (PR industry) as an additive in a high modulus asphalt concrete, they found a very good performance in terms of rigidity, a percentage of empty acer reduced and remarkable behavior with regard to fatigue. Recycled bituminous concrete reinforced with plastic granulates (PR-Plast-S) were studied by (Melbouci et al, 2014) [10] to carry out this study of Marshall and Duriez tests were carried out on various formulations, the results show that recycling of pavements can be performed without restrictions up to $30 \%$ of milled with plastic pellets mixtures behave like new asphalt above $6 \%$ addition of PR-PLAST-S.

Patel et al, 2017 [14] studied the partial replacement of ordinary aggregates by ceramic waste in an asphalt mixture with rates of $5,10,15$ and $20 \%$, the study is based on the determination of Marshall stability and in terms of value, the results found show that the introduction of ceramic waste into the bituminous mixture gives considerable values of Marshall stability and decreases for value.

Kara and Karacasu, 2017 [8] concluded that ceramic waste can be used with a limit of $30 \%$ or more because of its porosity and high absorption. Rubber aggregates have a positive influence on the strength of asphalt mixes and promote the use of this type of waste in the construction of flexible pavements (Meziani et al, 2013) [11]. Other researchers are interested in the recovery of waste in the foundation layers of pavement, (Hadidane et al, 2015) [6], (Leite et al, 2011) [9] studied the influence of demolition waste (concrete, brick, ceramic ....) on the behavior of the materials constituting the infrastructure of the roadway, they noted an improvement of the bearing capacity, modulus of elasticity and resistance to deformation. The possibility of using lateritic gravelly in the base layer is studied by (Seybatou et al, 2014) [5], they have demonstrated the improvement of the geotechnical properties of this waste by a cement treatment ( $4 \%$ assay) for their use in the basecoats. In another experimental study (Boudlal et al, 2015) [2] investigated the effect of glass aggregates on the mechanical properties of road granular mixtures, they concluded that a percentage of 10 to $25 \%$ of glass significantly improves the mechanical properties of mixtures. The replacement of crystallized slag as aggregates in the form and rolling layer is studied by (Rouabah and Guetteche, 2008) [15], they noted a drop in the stability of the mixture and an increase in the 
ratio $\mathrm{r} / \mathrm{R}$ and the void ratio depending on the increase in the substitution rate.

The aim of our research is to study the possibility of reusing the waste of the manufacture of tiles as aggregates in the construction of pavements precisely in the formulation of a severe asphalt for the base layer. This study will have ecological and economic benefits.

\section{USED MATERIALS}

The Ordinary aggregates used in this study are the fractions commonly used in Algeria for the manufacture of bituminous mixtures (heavy bitumen) for the preparation of basecoats, gravel 0/3, 3/8, 8/15 and 15/25 extracted of the EL-GHEDIR EST quarry of Algeria. Recycled aggregates are tiled waste (Fig. 1) obtained by crushing and screening the falls of the tiles, to obtain the granular classes (Fig. 2) 0/3, 3/8, 8/15 and 15/25.

The results of the identification tests of the aggregates are shown in table 1.

Figures 3 and 4 show the grain size curves of ordinary and recycled aggregates.

According to the results of the characterization tests it is found that:

- The apparent and absolute densities of recycled aggregates are lower than those of ordinary aggregates.

- According to the Los Angles and Micro Deval test, ordinary aggregates are harder compared to recycled aggregates.

- The sand equivalent of both types of aggregates are identical and indicate a clean sand.
- The porosity of recycled aggregates is very high compared to ordinary aggregates.

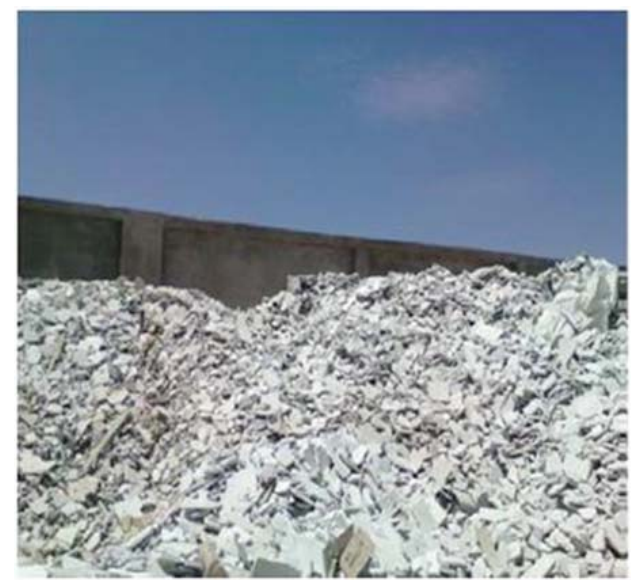

Figure 1: Waste tile

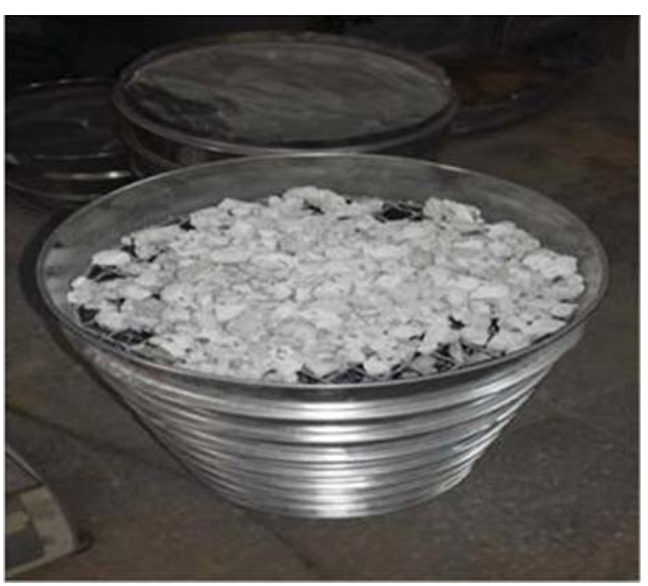

Figure 2: Granular class of recycled aggregates

Table 1: Physical and mechnical properties of the materials used

\begin{tabular}{|c|c|c|c|c|c|c|c|c|}
\hline \multirow{2}{*}{$\begin{array}{l}\text { Tests } \\
\text { Fraction }\end{array}$} & \multicolumn{4}{|c|}{ Ordinary aggregates } & \multicolumn{4}{|c|}{ Recycled aggregates } \\
\hline & $\begin{array}{l}\text { Sand } \\
0 / 3\end{array}$ & $\begin{array}{c}\text { Gravel } \\
3 / 8\end{array}$ & $\begin{array}{c}\text { Gravel } \\
8 / 15\end{array}$ & $\begin{array}{c}\text { Gravel } \\
15 / 25\end{array}$ & $\begin{array}{c}\text { Sand } \\
0 / 3\end{array}$ & $\begin{array}{c}\text { Gravel } \\
3 / 8\end{array}$ & $\begin{array}{c}\text { Gravel } \\
8 / 15\end{array}$ & $\begin{array}{c}\text { Gravel } \\
15 / 25\end{array}$ \\
\hline Apparent densty $\left(\mathrm{g} / \mathrm{Cm}^{3}\right)$ & \multicolumn{4}{|c|}{1.57} & \multicolumn{4}{|c|}{1.24} \\
\hline Absolute density $\left(\mathrm{g} / \mathrm{Cm}^{3}\right)$ & \multicolumn{4}{|c|}{2.81} & \multicolumn{4}{|c|}{2.37} \\
\hline Porosity (\%) & \multicolumn{4}{|c|}{2.62} & \multicolumn{4}{|c|}{13.9} \\
\hline Flattening (\%) & -- & 12.26 & 8.89 & 7.58 & -- & 7.67 & 7.17 & 5.35 \\
\hline Sand equivalent (\%) & 73.48 & -- & -- & -- & 73 & -- & -- & -- \\
\hline Blue value méthyléne (\%) & 0.85 & -- & -- & -- & 0.16 & -- & -- & -- \\
\hline Los Angeles (\%) & -- & -- & 23.67 & -- & -- & -- & 59 & -- \\
\hline Micro Deval (\%) & -- & -- & 10.22 & -- & -- & -- & 50 & -- \\
\hline
\end{tabular}




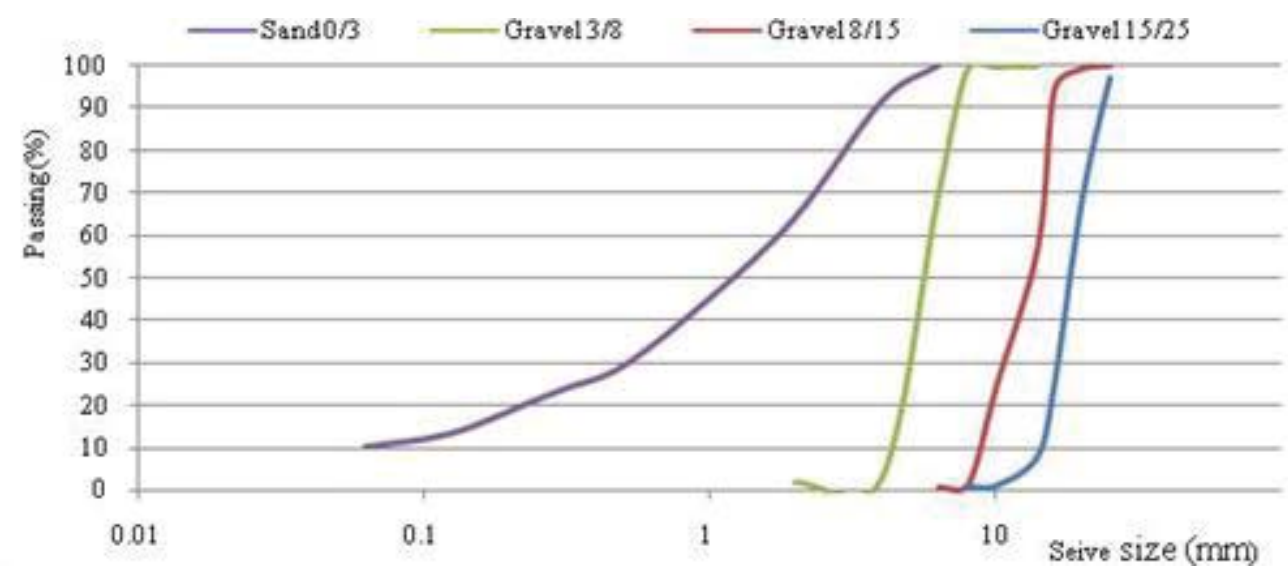

Figure 3: Granulometric cruve of ordinary aggregates

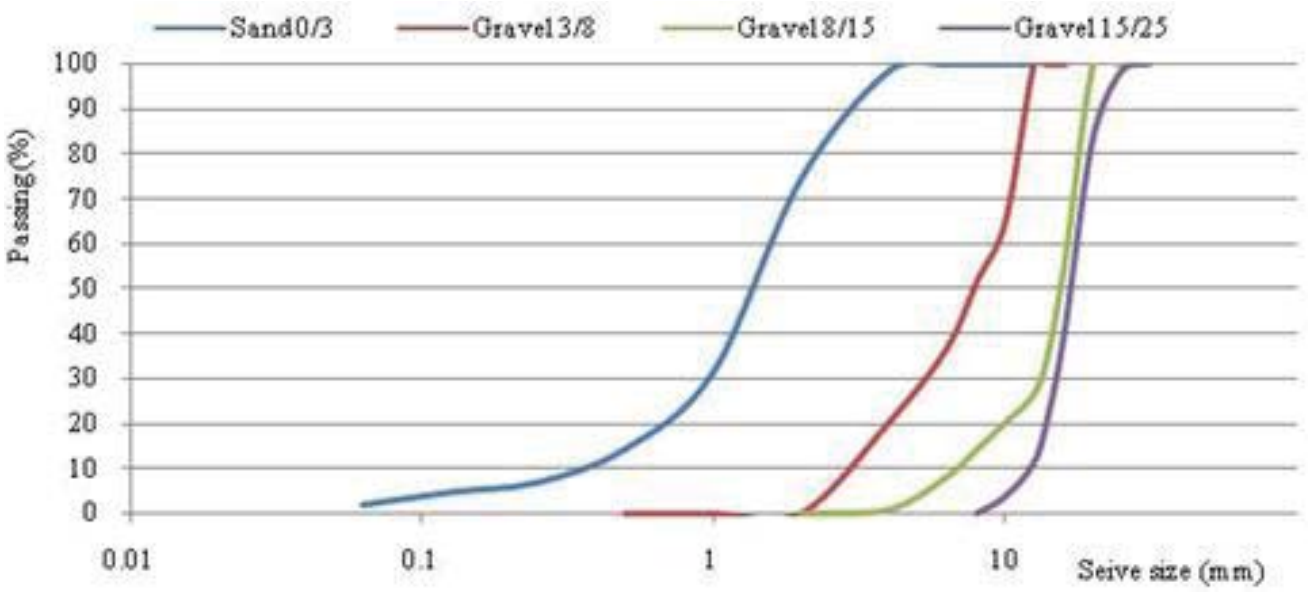

Figure 4: Granulometric curve of recycled aggregates

The hydrocarbon binder used is $40 / 50$ grade bitumen from NAFTAL East of Algeria, the main characteristics of this binder are shown in table 2.

Table 2: Characteristics of the aged binder

\begin{tabular}{|l|c|c|}
\hline \multicolumn{1}{|c|}{ Test } & Results & Specifications \\
\hline $\begin{array}{l}\text { Penetration at } 25^{\circ} \mathrm{C} \\
(1 / 10 \mathrm{~mm})\end{array}$ & 45 & $35-50$ \\
\hline Softening point $\left({ }^{\circ} \mathrm{C}\right)$ & 51 & $50-58$ \\
\hline Relative density at $25^{\circ} \mathrm{C}$ & 1,045 & 1.05 \\
\hline
\end{tabular}

\section{EXPERIMENTAL PROGRAM}

In the experimental program we replaced ordinary aggregates with recycled aggregates with rates of 10,20 and $30 \%$.

\section{FORMULATION}

The study of the formulation was conducted according to the following approach: choice of the granular formula, determination of the bitumen content and composition of the mixtures. In the approach codified in France (Junod et al., 2003) [7] in the 1950s, for a given particle size distribution, a minimum amount of bituminous binder is defined to ensure good durability of the mixture by the notion of modulus of wealth "K". This quantity, which is proportional to a conventional thickness of the binder film coating the aggregates, is given by the expression (1) (Robert, 2012) [16] which links "K" to the binder content "TL" and to the conventional surface area of the aggregates " $\Sigma$ ":

Taking into account that:

$$
\begin{aligned}
& T L=K \times \alpha \times \sqrt[5]{\Sigma} \\
& \alpha=\frac{2.65}{M V R}
\end{aligned}
$$

MVR: real volumic masse of granulate

K: reach model varied between 2.5 and 2.9 in the grave bitumen $0 / 20$

With:

- G: elements greater than $6.3 \mathrm{~mm}$.

- S: elements between $6.3 \mathrm{~mm}$ and $0.250 \mathrm{~mm}$.

- s: elements between $0.250 \mathrm{~mm}$ and $0.063 \mathrm{~mm}$

- $F$ : elements less than $0.08 \mathrm{~mm}$

\section{Choice of the formula}

From Fig. 5 and 6 it can be seen that the theoretical mixture is made in suitable proportions of the different granular classes, which fit into the specification zone of severe bitumen 0/20. 
- $\quad$ Mixing proposals are: $46 \%$ Class $0 / 3,12 \%$ Class $3 / 8,21 \%$ Class $8 / 15$ and $21 \%$ Class $15 / 25$.

- $\quad$ Module of equal wealth 2.75

- $\quad 5 \sqrt{ } \Sigma$ equals 1.51

- a equals 0.94

- $\quad$ The binder content (TL) is $3.9 \%$

\section{Test last according to standard NF P 98-250-1}

The purpose of this test is to determine the compressive strength of a specimen of asphalt with specified weights and cross sections. It also makes it possible to define the water resistance of the mix by the ratio of the compressive strengths after and before immersion of the specimen in a thermostatic water bath [13].
- The hydrocarbon mixture is compacted in a cylindrical mold $(\varnothing=120 \mathrm{~mm})$ by double-acting statistical pressure.

- The specimens are stored in water for the $18{ }^{\circ} \mathrm{C} \mathrm{im}$ mersion temperature and air compressive strength test for the air compression strength test (Figures 7 and 8). From this test we can determine:

- The resistance in air compression $\mathrm{R}$

- Resistance in compression to water $r$

- Water resistance ( $\mathrm{r} / \mathrm{R}$ ratio).

In the table 3 , the various formulations of the mixtures are presented.

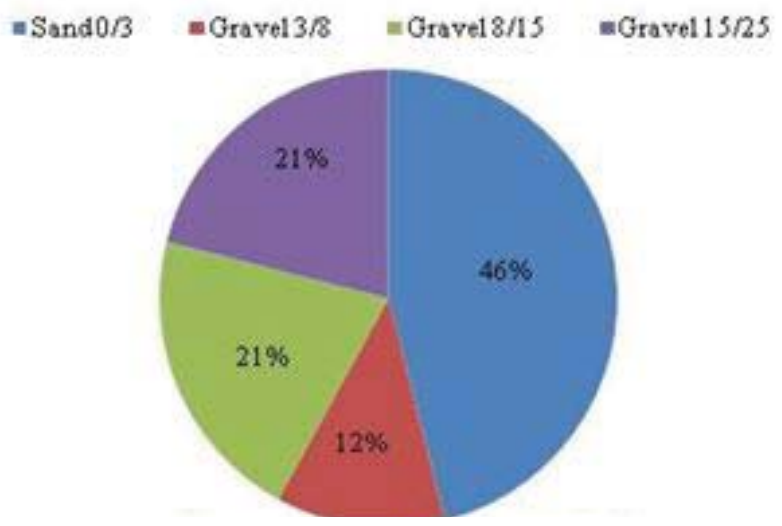

Figure 5: Granular composition

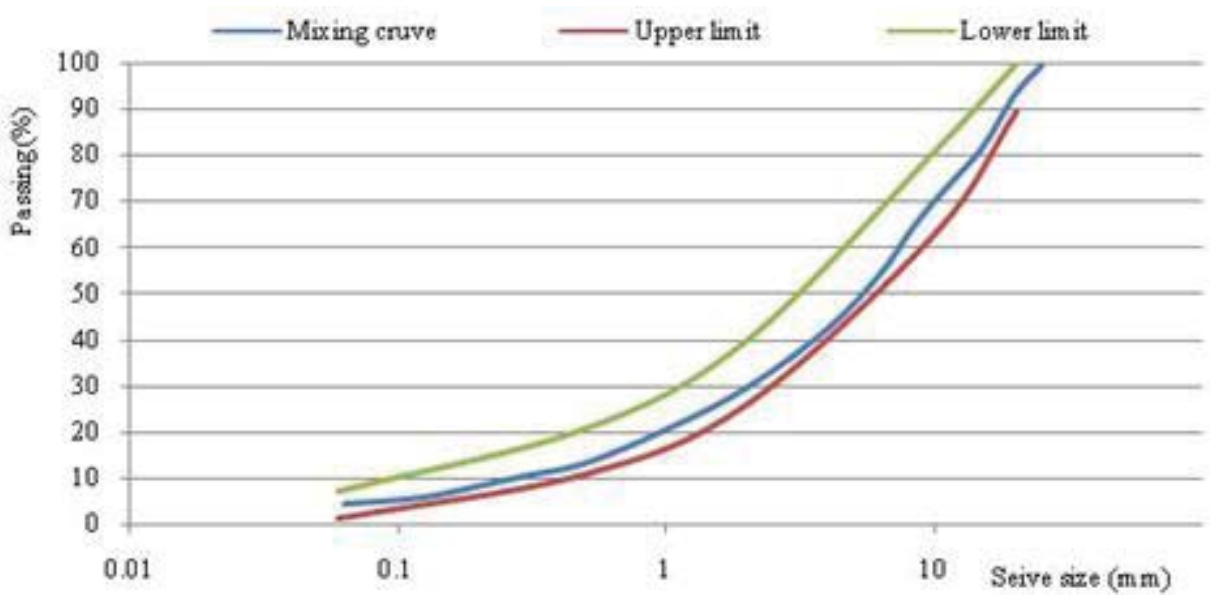

Figure 6: Grading curve of 0/20 bitumen mixtures

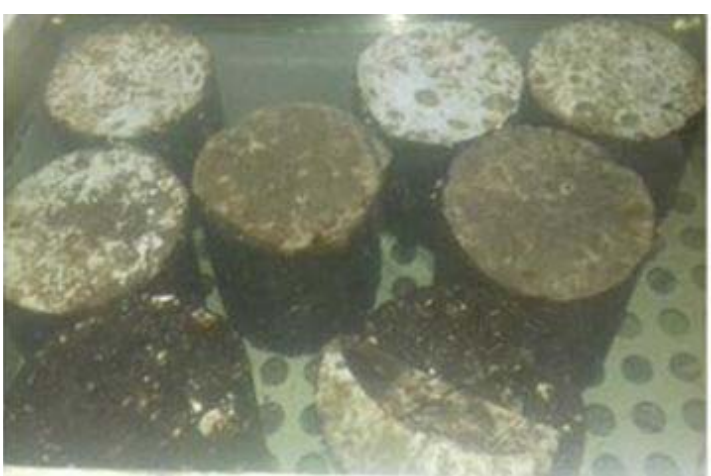

Figure 7: Conservation of test specimens with water

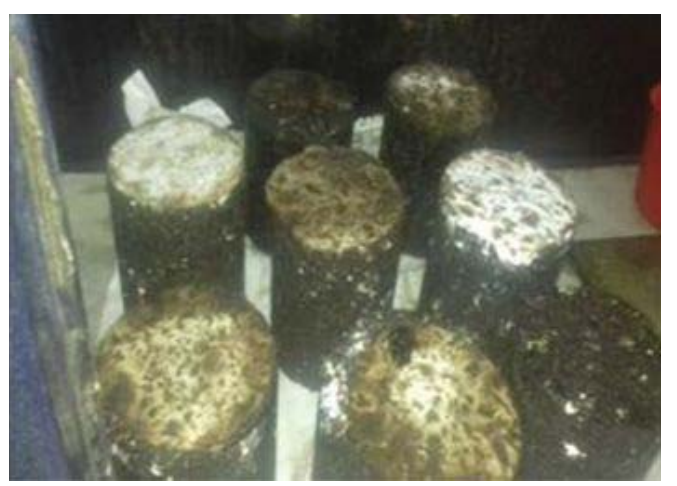

Figure 8: Perservation of specimens in the air 
Table 3: Deferent percentages of the materials in the tested test pieces

\begin{tabular}{|c|c|c|c|c|c|c|c|c|}
\hline Material & \multicolumn{4}{|c|}{ Ordinary aggregates } & \multicolumn{4}{c|}{ Recycled aggregates } \\
\hline $\begin{array}{c}\text { Fraction } \\
\text { percentage } \%\end{array}$ & $\begin{array}{c}\text { Sand } \\
0 / 3\end{array}$ & $\begin{array}{c}\text { Gravel } \\
3 / 8\end{array}$ & $\begin{array}{c}\text { Gravel } \\
8 / 15\end{array}$ & $\begin{array}{c}\text { Gravel } \\
15 / 25\end{array}$ & $\begin{array}{c}\text { Sand } \\
0 / 3\end{array}$ & $\begin{array}{c}\text { Gravel } \\
3 / 8\end{array}$ & $\begin{array}{c}\text { Gravel } \\
8 / 15\end{array}$ & $\begin{array}{c}\text { Gravel } \\
15 / 25\end{array}$ \\
\hline $0 \%$ & 6440 & 1680 & 2940 & 2940 & 0 & 0 & 0 & 0 \\
\hline $10 \%$ & 6160 & 1400 & 2520 & 2520 & 280 & 280 & 420 & 420 \\
\hline $20 \%$ & 5600 & 1120 & 2240 & 2240 & 840 & 560 & 700 & 700 \\
\hline $30 \%$ & 5040 & 840 & 1960 & 1960 & 1400 & 840 & 980 & 980 \\
\hline
\end{tabular}

\section{STABILITY DURIEZ}

\section{Apparent density}

Figure 9 shows that the density deprived as a function of the increase in substitution rate of recycled aggregates, this can be explained by the low density of recycled aggregates (Bourmatte, 2017)[16].

\section{Compactness}

Fig. 10 shows that the introduction of recycled aggregates leads to a reduction in the compactness of the severe control bitumen; this is explained by the high porosity of the recycled aggregates

\section{Percentage of voids}

In Fig. 11 we see that the volume of the voids aggregates increases with the increase in the substitution rate of recycled aggregates. The maximum value is 9.45 obtained by a rate of $30 \%$, this and due to the porosity of recycled aggregates; results are consistent with those found by (Rouabah et al, 2008) [15].

\section{Compressive strength}

Fig. 12 indicates that the introduction of the recycled aggregates leads to increase the compressive strength up to a rate of $10 \%$, beyond this rate the effect reverses. Conversation mode does not affect compression behavior. The maximum values are obtained for the rates of $10 \%$, since the minimum values are given by the rates of

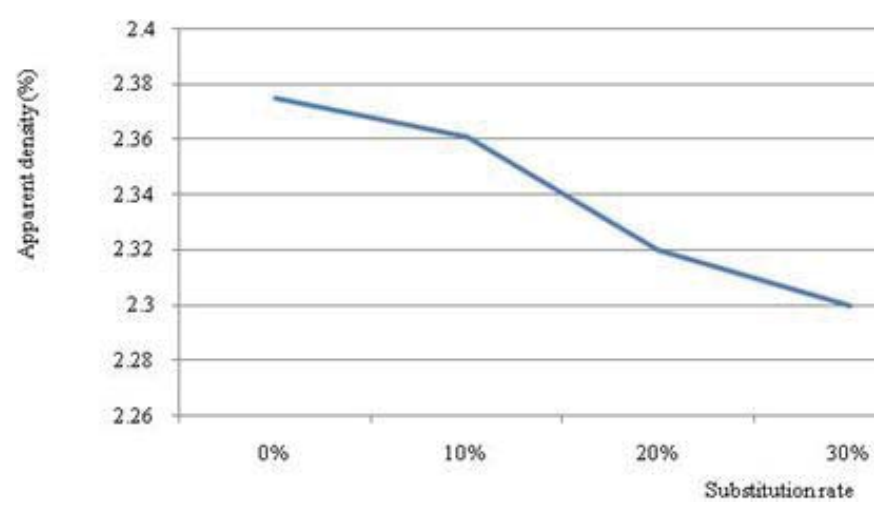

Figure 9: Density variation versus substitution rate
$30 \%$ of the recycled aggregates. These results are due to the porosity of the recycled aggregates on the one hand, and the decrease in compressive strength in the two conservation modes of the intrinsic properties of the recycled aggregates (Melbouci et al, 2014) [10].

\section{Water resistance ( $r / R$ ratio)}

The ratio $r$ / R (Fig. 13) increases with the increase of the degree of substitution to reach a maximum value at $20 \%$ of degree of substitution, this increase is explained by the very good aptitude of the mix to resist stripping under the action of water (Bendimerad and Zadjaoui, 2015) [3]. The minimum value of the ratio $r / R$ is given by the mixture of $30 \%$ substitution rate, this ratio remains acceptable and meets the specifications of the standards.

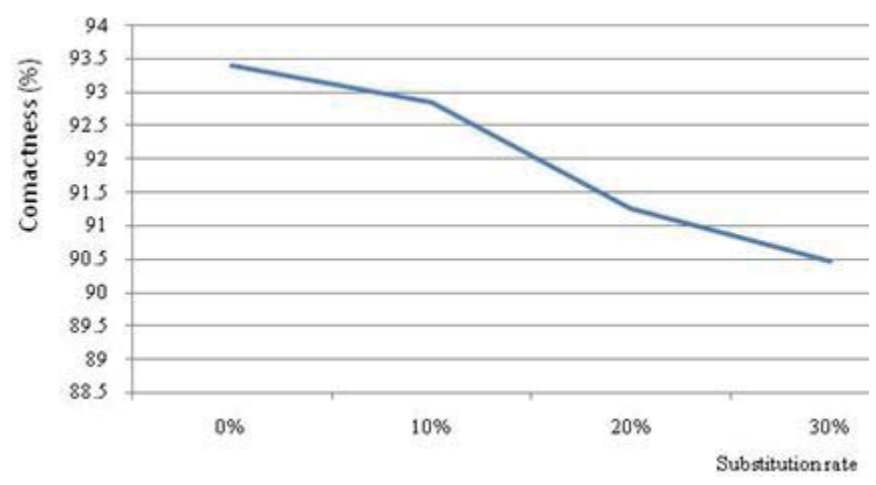

Figure 10: Variation in compactness versus substitution rate

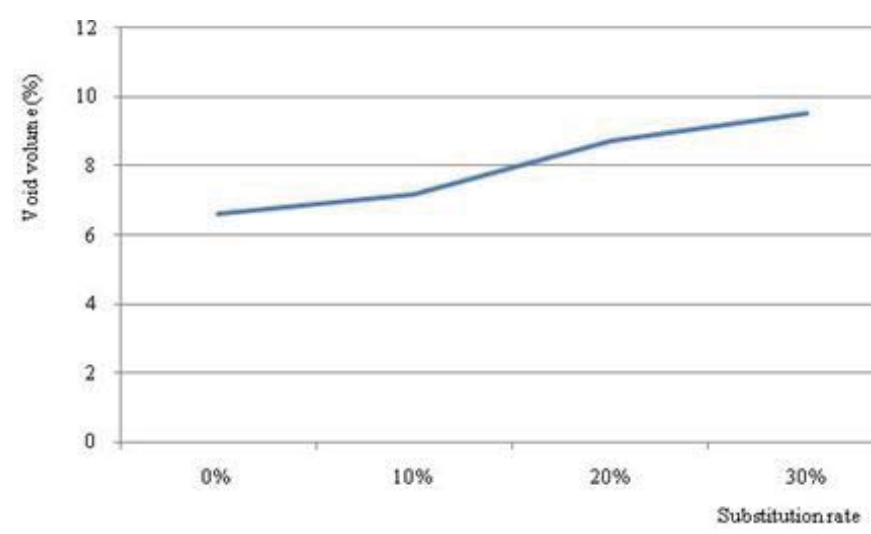

Figure 11: Variation in void volume versus substitution rate 


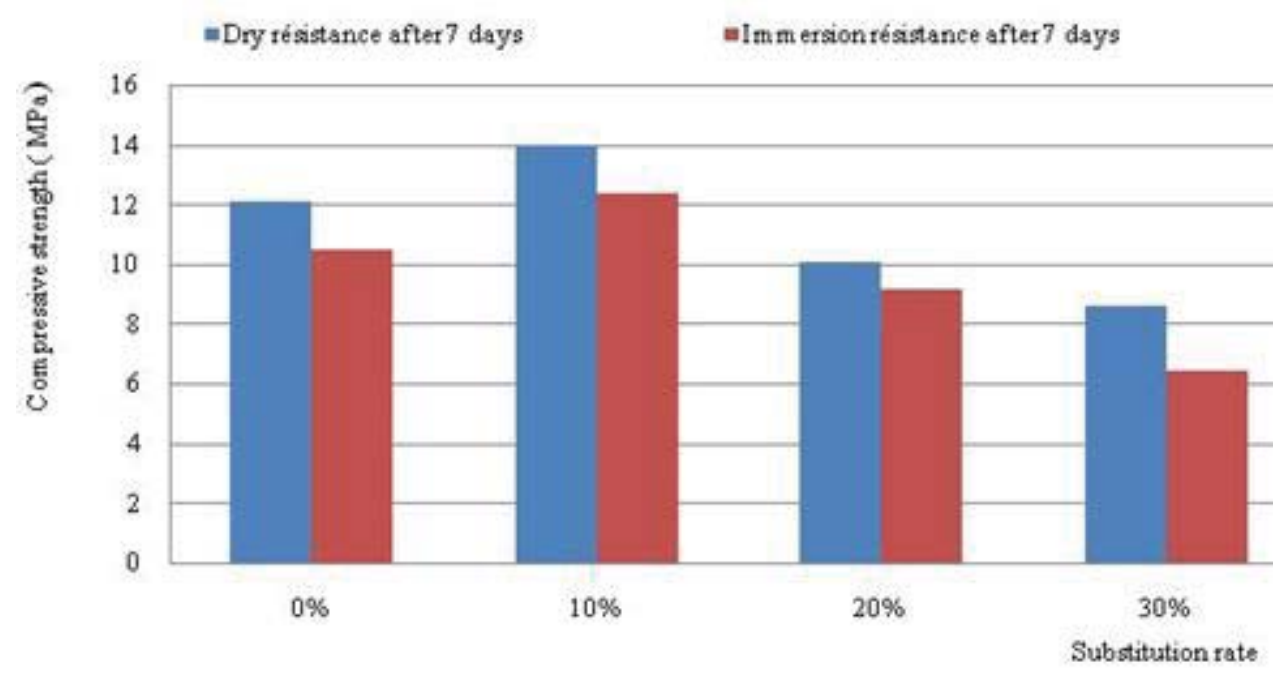

Figure 12: Variation in compressive strength versus substitution rate

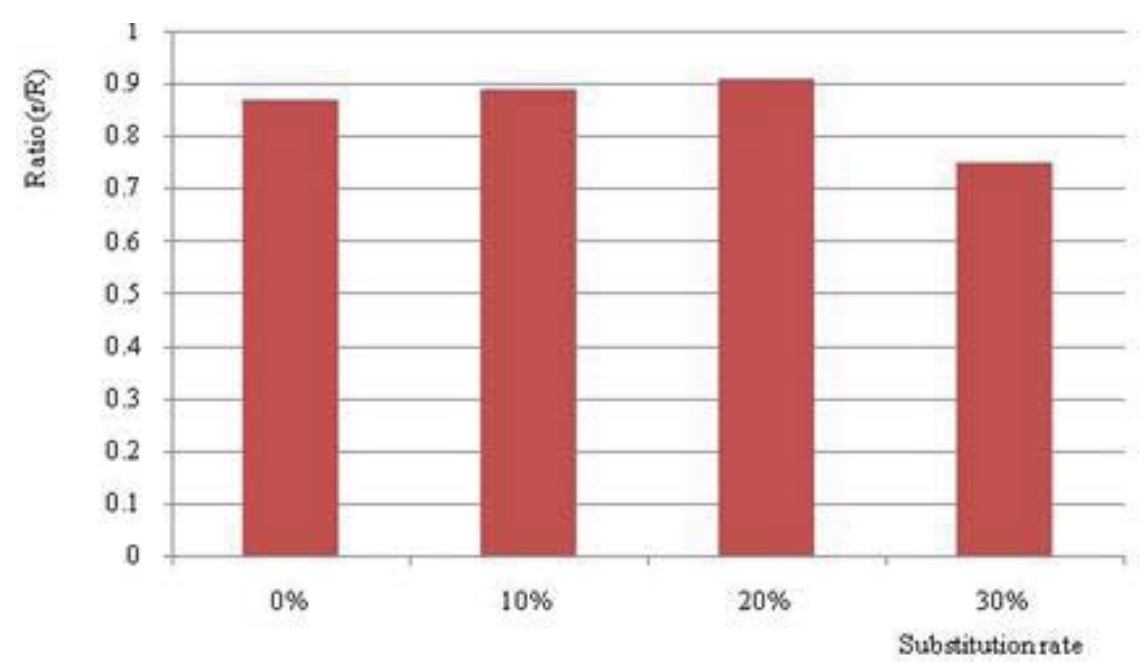

Figure 13: Water content variation by substitution rate

\section{CONCLUSION}

According to this study, which aims at the reuse of tiling waste in the formulation of a bituminous for the base layer, the following conclusions can be drawn.

- The introduction of recycled aggregates leads to a decrease in the density of the bituminous mixture.

- The compactness decreases according to the increase in the rate of substitutions of recycled aggregates.

- The void percentage increases with the increase of the substitution rate.

- The best performances in compression are given by the mixtures of $10 \%$ of substitution rate whatever the mode of conservation.

- The maximum $r / R$ ratio is recorded by the mixture of $20 \%$ substitution rate.

It can be concluded that it is possible to reuse tile waste in the road, this type of aggregates can become an alternative in terms of environment and economy.

\section{REFERENCES}

1. Bourmatte, N. (2017). Recycled aggregates of substitution in hydraulic concretes. PhD thesis. University of costantine.

2. Boudlal, O., Khattaoui, M., Djemai, M., Medani, M. (2015). Study of the mechanical behavior of a natural aggregates and glass mixture for use in road construction. 22nd French congress of mechanics, Lyon, 1-7.

3. Bendimerad, K.F.A., Zadjaoui, A. (2015). Control of the coating work with high modulus of asphalt concrete: Case of western Algeria.University meeting of civil engineering, Boyonne, France.

4. Cabrera, M.B., Satomi, T., Takahashi, H. (2017). Study on recycling of waste asphalt blocks containing roadbed materials using new screenless separation equipment with a vibration device. International Journal of Pavement Research and Technology, Vol. 10, 228-244. http://Doi.org/10.1016/j. iiprt.2017.01.006 
5. Diop, S., Samb, M., Diome, F., Fall, M. (2015). Materials characterization study of Sindia quarry (western Senegal) for use in road geotechnics. CAMES journal, Vol. $1, n^{\circ} 2,79-85$.

6. Hadidane, H., Oucief, H., Merzoud, M. (2015), Contribution to the improvement of behavior of assize's layers by the use of demolition debris. 13th Arab structural engineering, University of Blida, Algeria, 1-7.

7. Junod, A., Dumont, A.G. (2004). Formulation and optimization of asphalt formula, Polytechnic school of Lausanne (EPFL), (LAVOC), 1-81.

8. Kara, C., Karacasu, M. (2015). Use of ceramic wastes in road pavement design. Proceedings of the world congress on new technologies. Barcelona, Spain 2015, 226-6.

9. Leite, F.d. C., Motta, R.d.S., Vasconcelos, K.L., Bernucci, L. (2011). Laboratory evaluation of recycled construction and demolition waste for pavements, Construction and Building Materials, Vol 25, 2972-2979. https://doi.org/10.1016/j.conbuildmat.2010.11.105

10. Melbouci, B., Sadoun, S., Bilek, A. (2014), Study of strengthening of recycled asphalt concrete by plastic aggregates. International Journal of Pavement Research and Technology, Vol. 7, $\mathrm{n}^{\circ} 4,280-286$, Doi: 10.6135 /ijprt .org .tw/2014.7(4) .280
11. Meziani, F., Kahil, A., Gabi, S. (2013). Improvement of mechanical strength of flexible pavements by adding recycled tire aggregates. Communication Science and Technology, Vol. 12, 60-66.

12. Morsli, M., Rahab, K., Bali, A. (2013). Characterization of recycled asphalts. 31th Meeting of the AUGC.E .N.S. Cachan 2013, 1-11.

13. Norme NF P98-251-1. (2002). Essais statiques sur melanges hydrocarbonés, Partie 1: Essai Duriez sur mlanges hydrocarbones a chaud, 1-12.

14. Patel, J.V., Varia, H.R., Mishra, C.B. (2017). Design of bituminous mix with and without partial replacement of waste ceramic tiles material. International Journal of Engineering Research and Technology, Vol. 6, $\mathrm{n}^{\circ} 4,725-755$, Doi:10.17577//IJERTV6ISO40640.

15. Rouabah, K., Guetteche, M. N. (2008). Use of blast furnace slags in road construction. Science and Technology, B, $n^{\circ} 27,17-24$.

16. Robert, M. 2012. Route: matériaux, durabilite des chaussees, Master 2 genie civil, tome II, UniversitePaul sabatier, Toulouse, 34. 